\title{
Beda Arti Firman "Bacalah" dalam Pendidikan Islam-Kristen (Rekonstruksi Teks Baca-Tulis Dalam Pembelajaran)
}

\author{
Different Meaning Of The Word "Please Read" \\ In Islamic-Christian Education \\ (Reconstruction Of Text Reads In Learning)
}

\author{
Farida Asy'ari \\ Jurusan Teknik Mesin, Politeknik Negeri Pontianak \\ Jalan Ahmad Yani Pontianak 78124 \\ E-mail: Faridaasyari87@gmail.com
}

\begin{abstract}
Prompts for "reading" actually existed since when the revelation of God was revealed for the first time received by the prophet Muhammad SAW. In Holly Bible the book of Christians reveals that in the tradition of the Jewish command "Reading" after there is a book and reading to understand history and law. So before "reading" must do writing first. Thus, according to them, that the word of God "read" contained in his book is meaning "writing", which this thing is written directly in the book of output 17: 14 who was ordered to write history, and the book of Deuteronomy 4: 13-14 where God write 10 commands and teach commands. This research was conducted to find out and reveal the different meanings of the word "read" in Christian-Islamic Education. "Read-write" Text correlation in learning. The research method used is a theoretically oriented qualitative approach is a way of looking at the world, the assumptions that people embrace about something important, and what makes people work. So that the meaning of the word "read" in Islamic education means "reading" based on the word of God which first came down to the Prophet Muhammad, namely 'Iqra' in the letter Al-Alaq. Whereas in Christian education means "writing". Based on the word of God to the Prophet Moses in the book EXPLANATION 17: 14 in the Torah or the old agreement. The difference, the author tries to combine that reading and writing is a unity that cannot be separated in an education and learning. Therefore read-write that was not respected and preserved in learning must be rebuilt for the advancement of students as the nation's successor.
\end{abstract}

Keywords: God's Word Read, Christian Islam, learning

\begin{abstract}
Abstrak
Anjuran "membaca" sebenarnya sudah ada sejak dimana ketika diturunkan wahyu Tuhan untuk pertama kalinya yang diterima oleh nabi Muhammad SAW. Dalam Holly Bible Alkitab umat kristiani mengungkapkan bahwa dalam tradisi yahudi perintah "Membaca" setelah ada al-kitab dan membaca untuk memahami sejarah dan hukum. Jadi sebelum "membaca" harus melakukan penulisan terlebih dahulu. Dengan demikian, menurut mereka, bahwa firman Tuhan "Bacalah" yang tertuang dalam kitab nya adalah bermakna "menulis", yang hal ini tertera langsung dalam kitab keluaran 17: 14 yang diperintahkan untuk menulis sejarah, dan kitab Ulangan 4: 13-14 dimana Tuhan menulis 10 perintahnya dan perintah mengajar. Penelitian ini dilakukan untuk mengetahui dan mengungkap beda arti firman Tuhan "Bacalah" dalam Pendidikan Islam-Pendidikan Kristen. korelasi Teks
\end{abstract}


"Baca-tulis" dalam pembelajaran. Metode penelitian yang digunakan adalah Pendekatan kualitatif berorientasi teoritis adalah cara memandang dunia, asumsi yang dianut orang tentang sesuatu yang penting, dan apa yang membuat orang bekerja. Sehingga menghasilkan bahwa Arti firman "bacalah" dalam pendidikan Islam bermakna "membaca" berdasarkan firman Allah yang pertama kali turun kepada Nabi Muhammad saw yakni ' Iqra' pada surat Al-Alaq. Sedangkan dalam pendidikan Kristen bermakna "menulis". Berdasarkan firman Allah kepada Nabi Musa pada kitab KELUARAN 17: 14 didalam kitab Taurat atau perjanjian lamanya. Perbedaan tersebut, penulis mencoba memadukan bahwa membaca dan menulis merupakan satu kesatuan yang tidak dapat dipisahkan dalam sebuah pendidikan dan pembelajaran. Oleh karenanya baca-tulis yang dulu tidak diindahkan dan dilestarikan dalam pembelajaran harus kita bangun kembali demi kemajuan anak didik sebagai penerus bangsa.

Kata kunci: Firman Tuhan Bacalah, Islam Kristen, pembelajaran

\section{PENDAHULUAN}

Sampai saat ini masih ada public image bahwa "islamic learning" identik dengan kejumudan, kemandekan, dan kemunduran. Kesan ini di dasarkan pada kenyataan bahwa dewasa ini mayoritas umat Islam hidup di Negara-negara dunia ketiga dalam serba keterbelakangan ekonomi dan pendidikan. Lebih tragis lagi adalah berkembangnya cara berpikir serba dikotomis dan hitam putih sebagian besar umat Islam, seperti Islam vis-à-vis non Islam, timur-barat, dan ilmu-ilmu agama versus ilmu-ilmu sekuler (Secular sciences). (Mas'ud, 2002:1)

Hubungan Islam-Kristen di Indonesia acapkali disalahpahami menjadi pengkutuban barat-timur. Islam identik dengan timur dan kekristenan dengan barat. Padahal kedua agama semitik ini sama-sama memiliki asal-usul sejarahnya di timur tengah. Kendatipun harus diakui bahwa bentuk kekristenan di Indonesia adalah model kekristenan barat. Karena itu para penganut hubungan agama-agama di Indonesia berusaha mencari landasan yang kokoh untuk menanamkan (Winarto, 2016:Dialog)

Jurnal Eksos, Juni 2019, Th XV, No, 1
Undang-Undang Republik Indonesia No. 20 tahun 2003 tentang system Pendidikan Nasional (SISDIKNAS) 2003:7 "Pendidikan nasional berfungsi mengembangkan kemampuan dan membentuk watak serta peradaban bangsa yang bermartabat dalam rangka mencerdaskan kehidupan bangsa, bertujuan untuk berkembangnya potensi peserta didik agar menjadi manusia yang beriman dan bertaqwa kepada Tuhan Yang Maha Esa, berakhlak mulia, sehat, berilmu, cakap, kreatif, mandiri, dan menjadi warga Negara yang demokratsi serta bertanggung jawab”. Dalam merealisasikan tujuan pendidikan nasional tersebut, para praktisi pendidikan melahirkan ide-ide baru (masalah inovatif) dalam dunia pendidikan. Perguruan tinggi sebagai lembaga pendidikan formal mempunyai tugas dan tanggung jawab yang cukup besar dalam berusaha mencerdaskan pemikiran dan juga memberi inspirasi di berbagai sektor ilmu pengetahuan sesuai dengan masing-masing konsentrasi.

Anjuran "membaca" sebenarnya sudah ada sejak dimana ketika diturunkan wahyu Tuhan untuk pertama kalinya yang diterima oleh nabi Muhammad SAW. Dalam Holly Bible Al-kitab umat kristiani 
mengungkapkan bahwa dalam tradisi yahudi perintah "Membaca" setelah ada al-kitab dan membaca untuk memahami sejarah dan hukum. Jadi sebelum "membaca" harus melakukan penulisan terlebih dahulu. Dengan demikian, menurut mereka, bahwa firman Tuhan "Bacalah" yang tertuang dalam kitab nya adalah bermakna "menulis", yang hal ini tertera langsung dalam kitab keluaran 17: 14 yang diperintahkan untuk menulis sejarah, dan kitab Ulangan 4: 13-14 dimana Tuhan menulis 10 perintahnya dan perintah mengajar.

Adanya perseteruan konsep dan perbedaan wacana mengenai firman Tuhan "Bacalah" dalam perspektif Islam-Kristen, yang tak lain firman tersebut terkait erat dengan pembelajaran yang ada di dalam dunia pendidikan. Hal itu membuat peneliti tertarik dan simpatik untuk mengangkat dan menelitinya

Dalam hal ini ada dua alasan yang mendorong penulis untuk membahas masalah ini, yaitu: 1. Alasan Obyektif yakni pertama, Perlu adanya kajian secara mendalam mengenai beda arti firman "bacalah" yang mempunyai peranan tinggi dalam dunia pendidikan guna meningkatkan intelektual yang dimiliki oleh para pembaca lebih-lebih bagi para mahasiswa guna mendapatkan output yang benar-benar dapat diharapkan oleh seluruh lapisan masyarakat. Kedua, Mengkomparasikan pemahaman yang berbeda dalam perspektif pendidikan Islam dan pendidikan Kristen nampaknya merupakan sebuah keharusan bagi prakarsa pendidikan. Lebih-lebih bagi para pemerhati, praktisi, pecinta pendidikan, sekaligus sebagai tambahan pengetahuan bagi siapa saja yang membaca dan ingin mempelajarinya. Ketiga, Menulis, membaca, dan mengaplikasikan. Ketiganya memegang kunci penting yang harus diberlangsung teruskan dalam proses pembelajaran guna mencapai tujuan pendidikan dan tujuan lembaga yang diharapkan bersama. 2. Alasan Subyektif, pertama, Penulis memandang judul tersebut sangat relevan dengan pendidikan yang dibidangi dan diterjuni saat ini yaitu fakultas Tarbiyah jurusan PAI. Kedua, Judul tersebut dirasa asyik dan menarik untuk dikaji dan di tela'ah, guna membuka cakrawala berpikir yang sudah lama tak terjamah serta dirasa sangat mudah untuk dijangkau baik data maupun literature yang akan dikaji. Ketiga, Judul tersebut sangat berguna sekali dalam dunia pendidikan yang dapat dijadikan bahan bacaan, tela'ah, kajian serta bahan renungan guna memperluas keilmuan yang ada. Keempat, Adanya kesediaan dosen pembimbing untuk mengarahkan dan membimbing penelitian ini.

Tujuan dari Penelitian ini dilakukan untuk mengetahui dan mengungkap beda arti firman Tuhan "Bacalah" dalam Pendidikan Islam-Pendidikan Kristen. Serta korelasi Teks "Baca-tulis" dalam pembelajaran. Manfaat dari penelitian ini adalah sebagai penerapan teori ilmu pendidikan yang pernah penulis dapatkan di bangku kuliah dengan mata kuliah ilmu pendidikan, strategi belajar mengajar dan sejarah peradaban Islam . Dapat juga dijadikan sumber informasi ilmiah bagi pembaca guna menemukan kekurangan dan kelebihan dalam apa yang telah ditulis oleh peneliti. Dapat dijadikan bahan pertimbanagan dan bahan konsumsi intelektual guna memperluas pengetahuan yang dimiliki.

\section{METODE PENELITIAN}

Metode yang digunakan dalam penelitian ini adalah metode kualitatif yang prosedur penelitiannya mnghasilkan data 
diskriptif yakni usaha atau tulisan dan prilaku yang dapat diamati dari orang itu sendiri dan bersifat diskriptif berupa katakata tertulis atau lisan dari orang-orang dan prilaku yang diamati dan cenderung menggunakan pendekatan induktif.

\section{Pendekatan dan Jenis Penelitian}

Pendekatan kualitatif berorientasi teoritis adalah cara memandang dunia, asumsi yang dianut orang tentang sesuatu yang penting, dan apa yang membuat orang bekerja. Orientasi teoritis yaitu bermanfaat dalam mengumpulkan data dan menganalisis data. ( Moleong, 2004: 8) . Dalam penelitian kualitatif menggunakan metode kualitatif, penggunaan metode ini karena beberapa pertimbangan:

a. Menyesuaikan metode kualitatif lebih mudah apabila berhadapan dengan kenyataan ganda.

b. Metode ini menyajikan secara langsung hakekat hubungan antara peneliti dan yang diteliti.

c. Metode ini lebih peka dan menyesuaikan diri dengan banyak penajaman pengaruh bersama dan terhadap pola-pola yang dihadapai.

\section{Instrumen penelitian}

Sesuai dengan metode yang peneliti pakai dalam penelitian ini, yaitu penelitian kualitatif, maka instrumen inti dalam penelitian ini adalah peneliti itu sendiri dengan beberapa alat bantu yang dibutuhkan, serperti tape recorder, alat kamera, pedoman wawancara, alat tulis seperti ballpoint, pensil, buku catatan kecil, dan lainnya yang dibutuhkan secara insidental. Oleh karena itu, untuk menjamin validitas penelitian, maka diperlukan seorang peneliti harus divalidasi. Sugiyono (2005 : 59) mengatakan bahwa validasi terhadap peneliti sebagai instrumen meliputi validasi terhadap pemahaman metode penelitian kualitatif, penguasaan wawasan terhadap bidang yang diteliti, kesiapan Jurnal Eksos, Juni 2019, Th XV, No, 1 peneliti untuk memasuki obyek penelitian, baik secara akademik atau logistiknya. Sedangkan yang melakukan validasi terhadap peneliti adalah peneliti itu sendiri. Dengan melakukan analisis diri atau mempertanyakan kepada dirinya apakah sudah siap melakukan penelitian atau belum.

\section{Sumber data}

Sumber data utama dalam penelitian yang bersifat kualitatif ini adalah kata-kata, dan tindakan selebihnya adalah data tambahan seperti dokumen dan lain-lain. Namun dalam penelitian yang penulis kaji kali ini tak lepas dari sumber tertulis dan sumber lain yang mendukung.

a. Kata-kata dan tindakan

Kata-kata dan tindakan orangorang yang diamati atau diwawancarai merupakan sumber data utama.

b. Sumber tertulis

Data yang peneliti lakukan diambil langsung dari sumbernya, yakni kepustakaan berupa buku, jurnal, majalah dan sumber-sumber (Bacaan) lain yang mendukung terhadap materi penelitian ini. Sumber data yang digunakan adalah sumber data primer (Utama) dan sumber data sekunder (Pendukung

\section{Teknik pengumpulan data}

Teknik pengumpulan data dalam penelitian kualitatif diperoleh dari bukubuku pendidikan keislaman dan kristen serta bacaan lain yang mendukung terhadap penulisan ini. Peneliti juga menggunakan teknik pengumpulan data yang diperoleh dari dokumentasi. guna memperoleh data langsung dari tempat penelitian, yakni meliputi buku-buku yang relevan yang diambil dari perpustakaan kristiani dan datadata penting yang mendukung terhadap penulisan ini.

\section{Analisis Data}

Peneliti melakukan analisa data dengan catatan yang diperoleh dari literatur yang telah dikaji, serta dari dokumentasi, 
dengan cara mengorganisasikan data ke dalam kategori, menjabarkan ke dalam unitunit, melakukan sintesa, menyusun ke dalam pola, memilih mana yang penting dan yang akan dipelajari, dan membuat kesimpulan sehingga mudah dipahami oleh diri sendiri maupun orang lain.

Peneliti menggunakan analisis data kualitatif yang bersifat induktif, yaitu suatu analisis berdasarkan data yang diperoleh, selanjutnya dikembangkan menjadi hipotesis yang dirumuskan berdasarkan data tersebut, selanjutnya dicarikan data lagi secara berulang-ulang sehingga dapat disimpulkan apakah hipotesis itu diterima atau ditolak berdasarkan data yang terkumpul. Bila berdasarkan data yang dapat dikumpulkan secara berulang-ulang dengan teknik triangulasi, ternyata hipotesis diterima, maka hipotesis tersebut berkembang menjadi teori. Aktifitas yang dilakukan dalam penelitian ini yaitu

\section{a. Data reduction}

Mereduksi data berarti merangkum, memilih hal-hal yang pokok, memfokuskan pada hal-hal yang penting, dicari tema dan polanya. Jadi, pada tahap reduksi data ini yang dilakukan adalah menyeleksi, memfokuskan, menyederhanakan, mengabstraksikan, dan memformulasikan data yang relevan dengan fokus penelitian.

\section{b. Data display}

Setelah reduksi data selesai dilakukan, maka langkah berikutnya adalah menyajikan data. Kegiatan penyajian data merupakan kegiatan mengorganisasi sejumlah informasi yang telah direduksi. Sejumlah informasi yang diperoleh, diorganisasi dalam satu sajian informasi berdasarkan tata urut pengumpulan data. Semula data tersebut disajikan secara terpisah antara satu data dengan data yang lain, selanjutnya setelah keseluruhan data terkumpul pada akhir kegiatan akan disatukan kembali. Penyajian data terakhir ini sudah merupakan rangkuman dari keseluruhan temuan.

\section{c. Conclusion drawing/verification}

Yang dimaksud dengan Conclusion Drawing atau Verification ini adalah penarikan kesimpulan. Agar penarikan kesimpulan dapat dipertanggungjawabkan kebenarannya, maka peneliti melakukan diskusi dengan teman-teman yang sudah berpengalaman termasuk dosen pembimbing. Kegiatan seperti ini peneliti juga dilakukan setiap kali melakukan simpulan-simpulan lain, hingga akhir kegiatan penelitian. Dengan demikian, hasil akhir pembahasan penelitian ini merupakan hasil yang akurat, memunculkan teori, memperkuat dan menambah hasil penemuan sebelumnya.

\section{HASIL DAN PEMBAHASAN}

\section{Arti Firman Tuhan "Bacalah" dalam Pendidikan Islam}

Yang harus kita renungkan adalah ayat yang pertama turun yakni kalimat, “bacalah!”. Bisa saja wahyu yang pertama kali turun dimulai dengan kalimat lain , Akan tetapi Al-Qur'an yang yang turun selama dua puluh tiga tahun ini dimulai dengan kalimat , "bacalah!" (Hasbi ,1973: 159)

Padahal Nabi Muhammad adalah Ummi ( Tidak bisa membaca). Akan tetapi wahyu yang turun kepada penutup para nabi itu dimulai dengan menggunakan kalimat perintah yang jelas, to the point, ringkas, dan dalam satu kalimat yang mengandung arti sebagai pedoman hidup manusia, yakni katakata, "bacalah!". ( Ma'rifat, 2007: 57)

Dalam buku yang ditulis oleh Agus Nggermanto, 2003, Karena memandang sangat pentingnya membaca, mukjizat 
terbesar nabi, sekaligus kitab suci diberi nama Al-Qur'an. Secara harfiah Al-Qur'an berarti bacaan. Ayat-kalimat-pertama yang turun adalah Iq'ra'-bacalah. Ada yang merasa heran mengapa kata pertama dari ayat tersebut adalah Iqra' atau perintah membaca. Padahal Nabi tidak pernah membaca suatu kitab sebelum turunnya Al-Qur'an.

" Engkau tidak pernah membaca kitab sebelum Al-Qur'an, tidak pernah menulisnya dengan tanganmu karena jika demikian pasti akan bertambah ragu orang-orang yang mengingkarimu. (QS. 29: 48)."

Keheranan akan sirna jika di sadari arti iq'ra' dan disadari pula bahwa perintah ini tidak hanya ditujukan kepada pribadi nabi semata-mata, tetapi juga kepada setiap manusia sepanjang sejarah kemanusiaan.

Alhasil, perintah iqra' mencakup telaah terhadap alam raya, masyarakat dan diri sendiri, serta bacaan tertulis, baik suci maupun tidak. Demikian Quraih Shihab dalam tafsirnya (Pustaka hidayah 1997: 77). Pentingnya membaca dalam pandangan Islam, tergambar dalam kalimat pertama pada surat yang pertama turun kepada Rasulullah SAW yakni kalimat yang menyuruh beliau membaca dan memulainya dengan membaca nama Allah sebagaimana Firman Allah

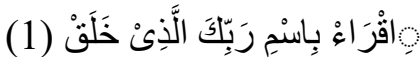
"Bacalah dengan menyebut nama Rabb-mu yang menciptakan" (Al-Alaq:1)

Lalu Allah mengulanginya lagi pada ayat berikutnya.

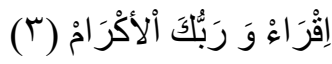

"Bacalah. Dan rabb-mulah yang maha pemurah." (Al-Alaq:3)

Sesungguhnya, Al-Qur'an berjumlah lebih dari 77.000 kata. Diantara kata-kata ini ada kata "bacalah!" dan ia merupakan wahyu yang pertama kali turun. Sebagaimana juga tercantum ribuan kalimat perintah dalam Al-Qur'an, "Dirikanlah sholat, bayarlah zakat, berjihadlah di jalan Allah, dan suruhlah berbuat baik dan cegahlah dari yang mungkar, bersabarlah atas musibah yang menimpamu, bertaubatlah kepada Allah, dan masih banyak lagi”. Diantara kalimat-kalimat perintah ini, yang pertama kali turun adalah kalimat "bacalah!", bahkan dalam surat itu kalimat "bacalah!" diulang dua kali.

Kata pena (Al-qalam) disebutkan sebagai penegas pada surat tersebut, sehingga perintah tersebut sangat kongkrit. Maksud dari membaca ialah membaca sesuatu yang di tulis dengan pena, tanpa ada kata-kata kiasan yang mengandung arti lain. (Yunus, , 1971: 37).

Dengan demikian "tahu" adalah tujuan dari membaca. Allah tidak memulai AlQur'an dengan kata-kata "Belajarlah", namun DIA menyebutkan dengan tegas, "bacalah!". sungguh, tidak ada keraguan bahwa di sana banyak cara untuk belajar, seperti dengan mendengar, melihat, pengalaman, dan latihan. Akan tetapi sarana yang paling agung tetaplah "Membaca". Dengan hal ini, seakan Allah mengajarkan kepada kita, bahwa meskipun di sana ada sarana yang banyak untuk belajar, namun kita harus tetap membaca. (Ahmad Musthafa, 1985: 328)

Seorang muslim adalah orang yang selalu seimbang. Ia perlu membaca banyak hal sehingga ia tetap seimbang. Sedangkan agama islam itu sendiri memiliki peranan dalam setiap sendi kehidupan kita. Di sini, penulis akan memaparkan sepuluh Prioritas yang harus di baca, namun bukan sesuatu yang mutlak. 
Prioritas pertama: Al-Qur'anul Karim. Hal yang pertama kali dan paling agung, dan kalimat terpenting untuk kita baca adalah Al-Qur'an. Bukan hanya sekedar kitab yang akan kita baca sekali atau dua kali, tetapi Al-Qur'an adalah undangundang bagi makhluk sehingga kita dituntut untuk terus menerus membacanya dengan konsentrasi.

Dalam hadist riwayat At-Tirmidzi, dari Abdullah Bin Mas'ud berkata "Rasulullah bersabda, 'Barang siapa yang membaca satu huruf dari kitab Allah, maka ia akan mendapat satu kebaikan. Kebaikan itu sendiri akan berlipat ganda menjadi sepuluh. Tidak aku katakan alif, lamm, miim itu satu huruf, tetapi alif satu huruf, laam satu huruf, dan miim satu huruf."' Jadi AlQur'an adalah Prioritas pertama kita perhatikan untuk dibaca.

Prioritas kedua: Al-Hadist As-Syarif. Banyak diantara kita yang membaca AlQur'an, tetapi sedikit sekali yang mata dan akalnya bersenang-senang dengan hadist. Hadist adalah salah satu gudang yang besar dari gudang-gudang yang bersama kita. Mulailah misalnya dengan membaca Riyadus sholihin, lu'lu' wal marjan.

Prioritas ketiga: ilmu-ilmu Syar'i. Kita bisa membangun pondasi yang kokoh dalam ilmu-ilmu syar'i mungkin dengan membaca, intisari tafsir Ibnu Katsir, buku ini merupakan buku tafsir Al-Qur'an yang bagus, kemudian membaca tafsir surat-surat yang kita hafal, Fiqhussunnah, Al-iman, dll.

Prioritas keempat: Buku-buku yang sesuai dengan spesialisasi ilmiah tertentu guna meraih suatu tujuan.

Prioritas kelima: Buku tentang analisis sejarah; karena sejarah sangat penting dan cukuplah sebagai bukti bahwa sepertiga Al-Qur'an adalah sejarah.
Prioritas keenam: Buku tentang politik, karena perubahan politik yang terjadi di bumi ini memiliki pengaruh tujuan yang sanat besar kepada umat islam.

Prioritas ketujuh: Buku tentang pendapat orang lain, misalnya tentang pendapat beberapa madhab.

Prioritas kedelapan: Buku tentang subhat seputar Islam, dalam rangka membantah tentang keraguan orang-orang tentang agama Islam.

Prioritas kesembilan: Buku tentang pendidikan anak

Prioritas kesepuluh: Buku tentang hiburan untuk merefrest otak yang mungkin mulai jenuh. (As-Sirjani, 1985: 47-65)

\section{Arti Firman Tuhan "Bacalah" dalam Pendidikan Kristen}

Jemaat yang mula-mula menganggap pengilhaman PL sebagai bagian yang pokok dan sangat penting dari ajarannya. Kitabkitab PB masih sedang ditulis selama abad yang pertama; jadi, ketika penulis-penulis PB menyebutkan "kitab suci", pada umumnya kitab-kitab yang kita kenal sekarang sebagai PL. Petrus menulis bahwa: "Tidak pernah nubuat dihasilkan oleh kehendak manusia tetapi oleh dorongan roh kudus orang-orang berbicara atas nama Allah" (II Ptr, 1:20-21).

Paulus memberitahu Timotius,

Segala tulisan yang diilhamkan Allah..." (II Tim. 3:16a). Dan karena Allah mengilhami tulisan-tulisan ini, itu "bermanfaat untuk mengajar, untuk menyatakan kesalahan, untuk memperbaiki kelakuan dan untuk mendidik orang dalam kebenaran. (II Tim. 3:16b). Hal ini diperkuat oleh J. I. Packer, Merril C. Tenney, William White, Jr, Ensiklopedi Fakta Al-Kitab (Bible Almanac), Buku rujukan Komperhensif yang direncanakan 
untuk mencari fakta tentang semua orang, tempat, dan adat istiadat di Alkitab (Malang: Yayasan penerbit gandum mas, 2001: 93.

Secara tradisional, gereja telah mengajarkan pengilhaman penuh al kitab. Dinyatakan dengan sederhana, inilah doktrin bahwa (1) Allah mengaruniakan dan menjamin segala sesuatu yang dikatakan para penulis alkitab mengenai semua pokok yang mereka bicarakan, dan (2) melalui dorongan batin (tambah penyesuaian dan pengendalian Ilahi) ia menentukan caranya mereka harus mengungkapkan kebenaranNya. Dengan demikian, al-kitab ditulis tepat seperti yang direncanakan Tuhan, dan karena itu sesungguhnya adalah firman Tuhan dan juga kesaksian manusia. Kedua ajaran ini berasal dari alkitab sendiri.

Para penulis PL berulang-ulang mengingatkan kita bahwa mereka sedang menyampaikan firman Allah. Para nabi membuka pernyataan mereka dengan mengatakan "Beginilah firman Tuhan, "Firman Tuhan yang datang kepadaku," atau pernyataan lain yang serupa.

Berikut ini ada beberapa ayat yang melukiskan hal ini:

Berfirmanlah Tuhan kepada musa, 'Tuliskanlah segala firman ini, sebab berdasarkan firman ini telah kuadakan perjanjian dengan engkau dan orang isra'el...", (Kel. 32: 27). "Semuanya itu terdapat dalam tulisan yang diilhamkan kepadaku (Daud) oleh Tuhan... "(I Taw. 28:19)".....datanglah firman ini dari Tuhan kepada Yeremania, bunyinya. Ambillah kitab gulungan dan tulislah di dalamnya segala perkataan yang telah kufirmankan kepadamu.... (Yer. 36: 1-2; bdg. ay. 21-32).

Setiap penulis menjelaskan bahwa ia sedang mencatat apa yang dinyatakan oleh Allah kepadanya, dan mengungkapkannya

Jurnal Eksos, Juni 2019, Th XV, No, 1 dengan kata-kata yang sama yang diterimanya dari Allah.

Menurut Boxter (MIA 93-1982), Sekalipun tidak disebut siapa pengarangnya, namun di dalam PB terdapat ayat-ayat yang menunjukkan bahwa Musa mempunyai peranan utama dalam menyusun pentatukh (Taurat yang 5), bahwa Imamat ditulis atas ilham dari Allah dinyatakan oleh Tuhan Yesus sendiri. Dibawah ini ada kutipan dari Imamat hukum 10 kitab Imamat 20: 1-7 yang menyangkut hukum yang sepuluh pasal. Kesepuluh firman 20: 1-17 dalam kitab Keluaran.

Lalu Allah mengucapkan segala firman ini : "Akulah Tuhan, Allahmu yang membawa engkau keluar dari tanah Mesir, dari tempat perbudakan. Jangan ada padamu Allah lain di hadapanku. Jangan membuat bagimu patung yang menyerupai apapun yang ada di langit diatas, atau yang ada di bumi di bawah, atau yang ada di air di bawah bumi. Jangan sujud menyembah kepadanya atau beribadah kepadanya, sebab aku Tuhan, Allahmu, adalah Allah yang cemburu, yang membalaskan kesalahan bapak kepada anak-anaknya, kepada keturunan yang ke tiga dan ke empat dari orang-orang yang membenci aku, tetapi aku menunjukkan kasih setia kepada beribu-ribu orang, yaitu orang yang mengasihi aku dan yang berpegang kepada perintah-perintahku. Jangan menyebut-nyebut nama Tuhan, Allahmu, dengan sembarangan, sebab Tuhan akan memandang bersalah orang yang menyebut namanya dengan sembarangan. Ingatlah dan kuduskanlah hari sabat: enam hari lamanya engkau akan bekerja dan melakukan segala pekerjaanmu, tetapi hari ketujuh adalah hari sabat Tuhan, Allahmu, maka jangan melakukan sesuatu pekerjaan, engkau atau anakmu laki-laki, atau anakmu perempuan, atau hambamu laki-laki atau hambamu perempuan, atau hewanmu atau orang asing yang di tempat 
kediamanmu. Sebab enam hari lamanya Tuhan menjadikan langit dan bumi, laut dan segala isinya, dan ia berhenti pada hari ketujuh, itulah sebabnya Tuhan memberkati hari sabat dan mengkuduskannya. Hormatlah ayahmu dan ibumu, supaya lanjut umurmu di tanah yang di berikan Tuhan, Allahmu, kepadamu. Jangan membunuh. Jangan berzinah. Jangan mencuri. Jangan mengucapkan saksi dusta tentang sesamamu. Jangan mengingini rumah sesamamu, jangan mengingini istrinya, atau hambanya laki-laki, atau hambanya perempuan, atau lembunya, atau keledainya atau apapun yang dipunyai sesamamu.

Perintah menulis ini, juga dipertegas dalam kitab Keluaran (17: 14) yang didalamnya diperintah untuk menulis sejarah

Kemudian berfirmanlah Tuhan kepada Musa: ' Tuliskanlah semua ini dalam sebuah kitab sebagai tanda penringatan, dan ingatkanlah ketelinga Yosua, bahwa aku akan menghapuskan sama sekali ingatan kepada Amelek dari kolong langit'.

Dalam kitab Ulangan (4: 13-14) Tuhan menulis 10 perintahnya dan perintah mengajar.

13 Dan Ia memberitahukan kepadamu perjanjian, yang diperintahkanNya kepadamu untuk dilakukan, yakni kesepuluh firman dan Ia menuliskannya pada dua loh batu. 14 dan pada waktu itu aku diperintahkan TUHAN untuk mengajarkan kepadamu ketetapan dan peraturan, supaya kamu melakukannya di negeri, kemana kamu pergi untuk mendudukinya.

Lalu Tuhan memerintahkan membaca. Yang tertuang dalam kitab Ulangan (31: 913)

9 setelah hukum taurat itu dituliskan Musa, maka diberikannyalah kepada imam-imam Bani Lewi, yang mengangkut tabut perjanjian TUHAN, dan kepada segala tua-tua Isra'el. 10 dan Musa memerintahkan kepada mereka, demikian: ' pada akhir tujuh tahun, pada waktu yang telah ditetapkan dalam tahun penghapusan hutang, yakni hari raya pondok daun, 11 apabila seluruh orang isra'el datang menghadap hadirat TUHAN, Allahmu, ditempat yang akan dipilihNya, maka haruslah engkau membacakan hukum Taurat ini di depan seluruh orang Isra'el. 12Seluruh bangsa itu berkumpul, laki-laki, perempuan, dan anak-anak, dan orang asing yang dian di dalam tempatmu, supaya mereka mendengarkan dan belajar takut akan TUHAN, Allahmu, dan mereka melakukan dengan setia segala perkataan hukum taurat ini, 13dan supaya anak-anak mereka, yang tidak mengetahuinya, dapat mendengarkan dan belajat takut akan TUHAN, Allahmu,-selama kamu hidup di tanah, kemana kamu pergi, menyebrangi sungai yordan untuk mendudukinya.'

Perintah membaca dilakukan setelah hukum Taurat yang difirmankan Tuhan kepada Musa telah rampung ditulis. Dan hasil tulisan itu dijadikan bahan pembelajaran seluruh kaum dimana berada.

\section{Baca-Tulis}

Membaca dan menulis mulai dianggap sebagai keterampilan wajib yang universal, perdebatan berlangsung antara mereka (Para pemerhati pendidikan) yang percaya anakanak paling baik belajar membaca dan menulis dengan menekankan arti dan pemahaman dulu.

\section{a. Baca-Tulis dalam Islam}

Dengan baca tulis, Al-Qur'an membangun peradaban. "Membaca" dalam aneka maknanya adalah syarat pertama dan utama pengembangan ilmu dan teknologi serta syarat utama membangun peradaban. Semua peradaban yang berhasil bertahan 
lama, justru dimulai dari satu kitab (bacaan). Peradaban yunani dimulai dengan Iliad karya Homer pada abad IX SM. Ia berakhir dengan hadirnya kitab perjanjian baru. Peradaban eropa diawali dengan karya Sir Isaac Newton (1641-1727) dan berakhir dengan filsafat Hegel (1770-1831). Sementara kehadiran Al-Qur'an peradaban Islam, khususnya dipicu oleh daya kekuatan yang tumbuh dari semangat ayat-ayat alQur'an yang awal mula diturunkan, yaitu perintah membaca dan menulis.

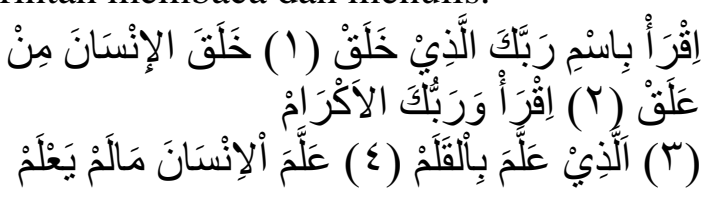

"Bacalah dengan menyebut nama Tuhanmu yang menciptakan, ia telah menciptakan manusia dari segumpal darah. Bacalah, dan Tuhanmulah Yang Maha Pemurah, yang mengajar (manusia) dengan perantaraan qalam. Dia mengajarkan kepada mnusia apa yang tidak diketahuinya." (Al-'Alaq : 1-5)

Dalam rangkaian wahyu Al-Qur'an yang turun perdana ini, iqro' atau perintah membaca merupakan kata pertama dan alangkah pentingnya kata ini ketika ia diulang dua kali. Kata iqro' yang terambil dari kata dasar qara'a pada mulanya berarti menghimpun. Arti kata ini menunjukkan bahwa iqra' yang diterjemahkan dengan bacalah tidak mengharuskan adanya teks tertulis yang dibaca, tidak pula harus diucapkan sehingga terdengar oleh orang lain.

Perintah membaca, menelaah, meneliti, menghimpun, dan sebagainya dikaitkan dengan kalimat "bismirobbika". Hal ini memberikan isyarat bahwa membaca apapun disyaratkan harus ikhlas, disamping memilih bacaan yang tidak mengantarkan kepada hal-hal yang bertentangan dengan nama Allah itu.
Bersama dengan seruan membaca, wahyu perdana dimuka juga memadukan perintah menulis, yang tersirat dari kata "AlQolam" 'pena'. Demikian pakar kontemporer memahami kata "Qolam" sebagai segala macam alat tulis-menulis sampai kepada mesin-mesin tulis dan cetak yang canggih. Anjuran menulis ditegaskan pada wahyu yang turun menyusul wahyu perdana itu.

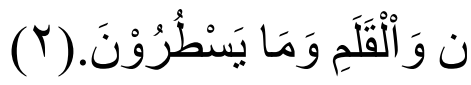

"Nuun, demi pena dan apa yang mereka tuliskan" (al-Qalam: 1)

Al-Qur'an diberikan nama Al-Kitab yang berarti 'tulisan yang tercatat dalam lembaran'. Tersirat dari sini akan pentingnya menulis disamping membaca.

Perintah iqra' mendorong agar umat manusia berpikir dan bertafakkur mempergunakan potensi akalnya, sementara kata AlQalam menyeru mereka untuk menulis dan mencatat (mengikat makna dan memonumenkan gagasan). Bisa dibayangkan bila ayat-ayat tersebut turun pada masyarakat yang tidak pandai membaca dan menulis (ummah ummiyah). Dari seruan ini lahir revolusi di masyarakat. Mereka jadi gemar menulis dan mengkaji apa saja, ayat-ayat kauniyah, lebih-lebih ayat Al-Qur'an.

Selain menyeru mendidik anak untuk membaca Al-Qur'an, Rasulullah juga menekankan pentingnya mendidik anak menulis huruf-huruf Al-Qur'an. Anak diharapkan memiliki kemampuan menulis (kitabah) aksara Al-Qur'an dengan baik dan benar dengan cara inilah 'dikte' atau setidaktidaknya dengan cara menyalin (nasakh) dari mushaf.

Pada masa kenabian, disiplin ilmu tulis menulis diberikan perhatian yang besar. Abdullah bin Sa'id bin Ash misalnya, mendidik banyak orang menulis di Madinah atas perintah Rasulullah. Ubadah ibnush 
Shamit berkata, "aku mendidik banyak orang dari kalangan Ahlus Suffah (penghuni selasar masjid) tulis-menulis dan membaca."

Sahabat wanita bernama asy-Syifa yang dikenal pandai menulis, sebagaimana diriwayatkan oleh Abu Daud, diperintahkan oleh Nabi untuk mengajari Hafshah salah seorang ibunda kaum muslimin, menulis dan mengobati.

Dengan usaha-usaha Rasul kegiatan dan tradisi tulis-manulis menjadi ramai, semarak, dan bergairah di kalangan kaum muhajirin dan anshar di Madinah, padahal sebelumnya mereka adalah ummah ummiyah, yaitu kaum yang tidak pandai baca tulis. Orang-orang yang pandai di bidang tulis-menulis sebelum itu sangat sedikit bahkan sulit dicari.

Semaraknya tradisi di kalangan generasi Islam pertama dan masa-masa berikutnya sesungguhnya merupakan penyambutan atas seruan Al-Qur'an sendiri di masa awal turunnya. Seperti diketahui, wahyu ke dua yang diturunkan adalah surat Al-Qalam.

Kitab suci Al-Qur'an sendiri diberi nama lain yang tidak kalah terkenalnya, yaitu al-kitab seperti yang telah diungkap diatas, yang berarti sesuatu yang tertulis. Tersirat dari nama ini, pentingnya memelihara al-qur'an dengan mengalakkan kegiatan tulis-menulis. (Syarifuddin, 1985: 69-67)

Bila mendidik anak membaca AlQur'an menjadi hak anak yang harus ditunaikan oleh orang tuanya, maka mendidik anak menulis Al-Qur'an juga menjadi hak anak yang wajib ditunaikan. Pepatah bijak yang terkenal menyatakan "ilmu ibarat binatang buruan, sedang menulis adalah pengikatnya. Ikatlah buruanburuanmu dengan tali pengikat yang kuat.
Termasuk kebodohan adalah kamu menangkap buruan sedang sesampai kamu melepaskannya kemudian (karena mengikatnya dengan kuat)."

Rasulullah memiliki juru tulis yang banyak sekali. Diantara mereka adalah sahabat Abu Bakar, Umar, Utsman, Ali, Ubay bin Kaab, Syurahbil bin hasanah, Muawiyah bin Abu Sufyab, Zaid bin Tsabit, Zubair bin Awwam, Khalid bin Walid, Amr bin Ash, Abdullah bin Rawahah, Handzalah bin Rabi', dan sahabat lainnya. Dari sekian juru tulis itu ada dua juru tulis yang intens yaitu Muawiyah dan Zaid bin Tsabit (AsSirjani, 1987: 32)

\section{b. Baca-Tulis dalam Kristen}

Sejak zaman purba paling dini di Asia barat, sekolah-sekolah digunakan untuk mengajar membaca dan menulis. Diantara orang Ibrani yang dilatih di Mesir, yakni Musa (Kis 7:22), diperintahkan untuk mengajarkan hukum kepada masyarakatnya

" Hari itu ketika engkau berdiri di hadapan Tuhan, Allahmu, di Horeb, waktu Tuhan berfirman kepadaku: Suruhlah bangsa itu berkumpul kepada$\mathrm{Ku}$, sehingga mereka takut kepad-Ku selama mereka hidup di muka bumi dan mengajarkan demikian kepada anakanak mereka." (UL 4:10) (Jakarta Lembaga: Al-kitab Indonesia, 2007: 197) dan perintah-perintah " Dan haruslah kamu dapat mengajarkan kepada orang isra'el segala ketetapan yang telah difirmankan Tuhan kepada mereka dengan perantara Musa." (Im 10:11).

Hal ini dilakukan dengan pengulangan dan contoh.

"Kamu harus mengajarkannya kepada anak-anakmu dengan membicarakannya, apabila engkau 
duduk dirumahmu dan apabila engkau sedang dalam perjalanan, apbila engkau berbaring dan engkau bangun"(UL 11:19) (Lembaga al-kitab Indonesia, 2007: 206) pembacaan dimuka umum (UL 31:10-13), dan menggunakan nyanyian-nyanyian yang digubah secara khusus (ay 19). Orang tua bertanggung jawab atas pendidikan anak-anak (Kej 18:19; Ul 6:7).

Dengan didirikannya tempat-tempat suci lokal dan bait Allah, maka para anak muda pasti diajar oleh para nabi dengan menggunakan sarana-sarana itu (1 sam 10:11-13; 2 raj 4:1). Diantara mata pelajaran lainnya, diajarkan juga membaca dan menulis (Hak 8:14; Yes 10:19). Abjad dipelajari dengan cara pengulangan (Yes 28:10; secara harfiah 'ts demi ts, q demi q...') namun kebanyakan pelajaran diberikan secara lisan dengan tanya jawab.

Para murid (Limmudin, 'pengikut') diajar oleh para nabi (Yes 8:16; 50:4; 54: 13), demikian juga raja-raja (Mis 2 Sam 12:1-7). Tidak ada acuan langsung dalam PL tentang gedung-gedung sekolah khusus. Tapi diperkenalkan pendidikan dasar sebagai keharusan bagi anak laki-laki umur 6-16 tahun di Yehuda pada kr tahun $75 \mathrm{sM}$ oleh Simon Bin Shetah. Ini menunjukkan sudah ada sekolah macam itu pada zaman bait Allah yang ke dua. 1 Taw 25:8 mengacu kepada para terpelajar (Talmid) pada zaman bait Allah yang pertama.

Dalam pengaruh kebudayaan Mesopotamia sesudah lk $3000 \quad$ sM pendidikan memegang peranan yang sangat penting. Nampaknya buku-buku sekolah dan kurikulum Mesopotamia ditiru di Anatolia, Siria dan juga Palestina. Tentang pendidikan Mesopotamia dan peranan para juru tulis, Lih S. N Kramer, the Sumerians, 1963, hlm 229-248: tentang orang Mesir Lih R.J Williams, JAOS 92, 1972, hlm 214-222.
(The New Bible Dictionary, Ensiklopedi AlKitab masa kini, , (Jakarta: Yayasan Komunikasi Bina Kasih/omf, 2001: 372)

Begitupun dalam PB tidak ada petunjuk apapun mengenai sekolah bagi anak-anak Ibrani. Agaknya rumah tangga menjadi sarana pendidikan dasar. Sinagoge merupakan pusat pengajaran agama yang dilakukan oleh para ahli Taurat (Mat 7:29; Luk 4: 16-32; Kis 19:9). Kata 'sekolah' muncul hanya satu kali (Kis 19:9) TBI 'ruang kuliah', tak ada petunjuk apakah ruang kuliah 'Tiranus' diperuntukkan bagi pendidikan dasar (6-14 thn) atau untuk mata pelajaran lanjutan kurikulum yunani seperti filsafat, kesustraan dan retorika (14-18thn). Suatu tambahan 'barat' terhadap Kis 19:9 berbunyi, 'dari jam kelima sampai jam kesepuluh'. Ruang kuliah tiranus dapat di sewa mulai jam 11.00 pagi dan seterusnya. Pelajaran-pelajaran dimulai pada dini fajar secara simultan, berkaitan dengan kewajiban panggilan paulus sendiri (Kis 18:3). Ia menggunakan waktu sore untuk mengajar di rumah-sekolah sewaan.

Diseluruh Asia barat Kuno, sejak paling sedikit thn 3100 sM dan selanjutnya, tulisan merupakan tanda peradaban dan kemajuan. Pada millenium 2 sM ada beberapa percobaan yang menjurus kepada pengembangan abjad, dan dampaknya ialah meningkatnya jumlah orang yang melek huruf. Kendati sampai sekarang baru sedikit dokumen yang ditemukan di Palestina sebelum periode pembuangan di bandingkan ribuan dokumen yang di temukan di Mesir, Siria, dan Mesopotamia, toh masuk akal untuk menganggap bahwa dekatnya Palestina dengan pusat kebudayaan lain membuatnya dapat mengambil bagian dalam seni karya tulis sepanjang kurun waktu itu. Kata-kata yang paling lazim untuk tulisan 
(Ibrani katav; Aram k tav; Yunani grafo) muncul lebih dari 450 kali dalam PL dan PB.

Pada zaman Israel kuno, sebagaimana di semua negri kuno di Asia Barat, hanya sedikit orang yang tahu seni baca-tulis. Karena itu profesi juru tulis sangat di hormati. Kata untuk juru tulis dalam bahasa Ibrani (Sofer dari Safar'menghitung, bercerita: bentuk Pi'el.'menghitung kembali'). Ugarit (spr)dan akad (saparu,. 'mengirim, menulis') mencakup tugas-tugas pokok dari pekerjaan yang menuntut keterampilan tinggi ini. Banyak juru tulis yang dibutuhkan oleh umum sebagai penulis untuk menyalin perjanjian-perjanjian hukum yang di perlukan (Yer 32:12), menulis suratsurat, atau mencatat hal-hal atau diimlakan (Yer 36:26). Yang lainnya dikenal sebagai juru tulis raja' (2 Taw 24:11), ditugasi untuk urusan administrasi umum dan dikaitkan dengan rumah tangga istana, dimana juru tulis kepala bertindak sebagai 'panitera negara' dan urutan jabatannya mendahului panawarikh (Mazkir), yang menyimpan catatan-catatan negara (2 Sam 8:16; 1 Raj 4:3). Sebagai pejabat tinggi, panitera Negara adalah salah seorang penasihat raja (1 Taw 27: 32).

\section{Baca-Tulis dalam Pembelajaran}

Seorang guru terkadang lupa akan pentingnya baca tulis untuk diajarkan di dalam kelas kepada murid-muridnya. Mary Leonhardt merupakan seorang guru yang pemerhati baca membaca mengajak kita semua, orang tua, dan guru untuk menanamkan kebiasaan membaca pada anak sedini mungkin. Ada beberapa alasan mengapa kita harus menumbuhkannya.

Pertama, anak-anak harus gemar membaca agar mereka dapat membaca dengan baik.

Kedua, anak-anak yang gemar membaca akan mempunyai rasa kebahasaan yang lebih tinggi, mereka akan bebicara, menulis, dan memahami gagasan-gagasan rumit secara baik.

Ketiga, membaca akan memberikan wawasan yang lebih luas keragamannya, yang dapat membuat belajar dalam segala hal menjadi lebih mudah.

Keempat, di Sekolah Menengah Umum nanti, hanya anak yang gemar membaca yang akan mempunyai keterampilan bahasa yang unggul dalam setiap bidang.

Kelima, kemampuan istimewa membaca dapat mengurangi rasa tidak percaya diri.

Keenam, membaca akan memberikan beragam perspektif kepada anak.

Ketujuh, dapat menumbuhkan rasa kasih sayang, yang dapat memahami dan membawa anak pada kehidupan yang berbeda yang kompleksitas.

Kedelapan, mereka akan dihadapkan pada suatu dunia yang penuh dengan kemungkinan dan kesempatan. Yakni mereka dapat memimpikan apapun dan pergi kemanapun.

Kesembilan, mereka akan mengembangkan pola pikir kreatif. Mereka tidak hanya mendengar informasi, akan tetapi belajar mengikuti argument-argumen yang kaya dan mengingat alur pemikiran yang beragam.

Kesepuluh, kecintaan membaca adalah salah satu kebahagiaan utama dalam hidup. (Mary Leonhardt ,2000:29)

Banyak kalangan merasa prihatin terhadap rendahnya minat baca siswa Indonesia. Bahkan berdasarkan survei International Education Achievement (IEA), kemampuan membaca kelas VI SD Indonesia berada pada tingkatan paling 
rendah setelah Hongkong, Singapura, Thailand, Filipina, dan Indonesia. Dari berbagai keprihatinan minat baca itu, tentu para gurulah yang paling tertimpa musibah. Karena hampir setiap hari guru dan siswa bertemu di kelas untuk melaksanakan proses belajar mengajar (PBM). Padahal ketika PBM, tentu dilakukan kegiatan membaca, baik membaca angka maupun huruf.

Menulis adalah bentuk keterampilan dan pengetahuan yang banyak melibatkan kemampuan siswa. Dalam sebuah tulisan terkandung ide sang penulis untuk disampaikan kepada orang lain. Kurangnya kemampuan siswa dalam menulis tidak perlu disikapi dengan mengatakan bahwa hal itu terjadi karena ditiadaknnya pelajaran mengarang dalam pelajaran bahasa Indonesia. Kemampuan menulis tidak ditentukan oleh ada dan tidaknya pelajaran mengarang.

Ada beberapa cara yang harus dilakukan agar siswa terbiasa menulis. Pertama, mengajarkan kepada siswa berbagai bentuk-bentuk tulisan yang benar, misalnya bentuk huruf capital dan bentuk huruf kecil yang harus dipakai. Dari sejak dini, kita harus mengajak siswa untuk melakukan hal-hal yang benar. Jangan membiarkan mereka terus menerus melakukan kesalahan. Kedua, memperbanyak kosa kata dalam berbahasa. Hal itu dalam rangka mempermudah siswa mengungkapkan ide, pendapat ataupun pengetahuannya ke dalam bahasa tulis. Karena setelah menguasai banyak kosa kata, kita ajak siswa untuk merangkainya dalam sebuah kalimat yang memiliki makna yang dapat dipahami oleh pembaca. Ketiga, membiasakan pembuatan garis-garis besar yang akan di tulis. Dengan ini siswa diharapkan tidak melupakan poin-poin yang harus hadir dalam tulisannya. Keempat, membiasakan pembacaan ulang, bila perlu sampai tiga kali, apa-apa yang sudah di tulis. Respon terhadap tulisan yang dibaca siswa akan memberikan gambaran pada aspek kognitifnya untuk memahami apa yang dibacanya. Oleh karena itu, seorang guru harus memberikan kebebasan kepada siswa untuk menulis apasaja yang mereka ketahui dan apa yang ingin mereka kemukakan. (Tresnawati,2005: 45-47)

Untuk mendapatkan hasil yang maksimal, diupayakan kepada para guru dari beberapa mata pelajaran untuk mengadakan kerjasama dalam mengajak murid untuk tetap melakukan aktivitas tulis menulis. Dengan bentuk pengajaran kepedulian seperti di atas, diharapkan kepada siswa dapat memenuhi kemampuan yang harus mereka miliki setelah menyelesaikan satu jenjang pendidikan (Tresnawati,2005: 47).

Guru dapat menerapkan pembelajaran menulis melalui tiga cara yaitu: 1) menjelaskan materi; 2) melatihkan sesuatu; dan 3) melibatkan siswa dalam kegiatan berbahasa. Cara yang ketiga merupakan cara yang paling efektif karena siswa yang menjadi fokus (aktif). Yang dipentingkan adalah proses siswa mengalami kegiatan menulis tanpa mengesampingkan hasil pembelajaran yang diperoleh. Pembelajaran semacam ini adalah pembelajaran yang tidak dipusatkan pada materi, tetapi pada kompetensi.

Disini peneliti akan memaparkan beberapa langkah yang mungkin dapat dipertimbangkan untuk pengembangan program pengajaran baca-tulis, diantaranya:

a Di kelas, guru harus selalu mengajukan pertanyaan-pertanyaan tentang isi (berbagai) buku rujukan. Berikan juga kesempatan kepada mereka untuk berkomentar tentang apa yang dibacanya, baik secara lisan maupun tertulis. 
b. Rekomendasikan berbagai buku yang akan menjadi buku pegangan siswa (di tingkat SD, SMP dan SMA misalnya). Rekomendasi itu haruslah dengan pertimbangan yang berdasar.

c. Hilangkan citra (momok) buku pelajaran di sekolah hanya sebagai satu komoditi dan sering digonta-ganti, sebaliknya tiap buku menjadi komplementer dari buku lainnya.

d. Berikan penghargaan yang selayaknya kepada mereka yang lebih banyak membaca

e. Di tingkat pemerintahan dan badan usaha, terutama milik negara, berikan penghargaan kepada orang yang ahli untuk dipekerjakan di bidangnya. Dengan kata lain capability-nya dijadikan pertimbangan utama.

Semestinya, setiap guru adalah dari kalangan para pembaca efektif, dan yang aktif pula mengajarkan tulis baca dalam arti yang luas. Harapan kita terhadap pendidikan yang lebih bermutu hanya akan bisa disahuti oleh para guru yang masuk kategori pembaca efisien-efektif. Tidaklah tepat anggapan kalau yang menjadi guru tulis baca itu hanyalah guru bahasa saja.

Guru yang efektif itu adalah guru yang pandai berkomunikasi dengan baik dengan siswanya. Ini mensyaratkan seorang guru berkemampuan bahasa yang baik, gemar membaca, mengikuti perkembangan bidang ilmu yang ditekuninya.

Pembelajaran itu sendiri merupakan suatu upaya membelajarkan atau suatu upaya menggerakkan aktivitas siwa kearah aktivitas belajar. Di dalam proses pembelajaran terkandung dua aktivitas yaitu mengajar (guru) dan aktivitas belajar (siswa) (Rohani, 2004: 161). Dalam pembelajaran, guru, dan bahan-bahan pelajaran, baik buku bacaan atau semacamnya merupakan hal yang urgent untuk meningkatkan daya produktif siswa dalam tulis menulis.

\section{SIMPULAN}

Dari beberapa paparan yang peneliti sajikan mengenai tela'ah beda Arti Firman "Bacalah" dalam pendidikan Islam dan pendidikan Kristen dapat kami simpulkan bahwa:

1. Arti firman "bacalah" dalam pendidikan Islam bermakna "membaca" berdasarkan firman Allah yang pertama kali turun kepada Nabi Muhammad saw yakni ' Iqra' pada surat Al-Alaq. Sedangkan dalam pendidikan Kristen bermakna "menulis". Berdasarkan firman Allah kepada Nabi Musa pada kitab KELUARAN 17: 14 didalam kitab Taurat atau perjanjian lamanya

2. Adanya perbedaan arti tersebut, penulis mencoba memadukan bahwa membaca dan menulis merupakan satu kesatuan yang tidak dapat dipisahkan dalam sebuah pendidikan dan pembelajaran. Oleh karenanya baca-tulis yang dulu tidak diindahkan dan dilestarikan dalam pembelajaran harus kita bangun kembali demi kemajuan anak didik sebagai penerus bangsa.

\section{Saran}

Setelah peneliti memaparkan, menganalisa data dan menyimpulkan, tidak salah kiranya apabila memberikan sedikit saran kepada pembaca tulisan ini.

1. Baca-tulis hendaknya masih tetap dilestarikan dalam pembelajaran dan dalam institusi pendidikan yang bertujuan agar lulusan dari jenjang pendidikan yang anak didik tekuni dan mereka bidangi sesuai dengan harapan semua pihak.

2. Hendaknya para guru tetap eksist untuk mengajarkan baca-tulis dalam mata 
pelajaran yang diberikan kepada siswa guna memperlancar dan membiasakan anak didik. Yang tidak hanya terfokus pada bidang pelajaran bahasa Indonesia.

3. Himbauan kepada seluruh anak didik untuk tetap semangat dan tidak mengesampingkan pembelajaran bacatulis. Karena membaca merupakan "Jendela untuk melihat dunia" dan menulis merupakan salah satu sayap untuk mengungkap realitas kenyataan yang kita temui dari membaca. Baik membaca buku, membaca alam, dan membaca segala aspek sisi kehidupan yang penuh dengan problematika hidup yang disajikan oleh sang penguasa alam raya.

4. Kepada para pembaca, baik dari kalangan konglomerat, pakar pendidikan, pemerhati pendidikan, praktisi pendidikan, maupun mahasiswa yang masih bergelut dalam dunia pendidikan. Yang pasti tulisan ini masih banyak mengalami kekurangan dan pembenahan kearah yang lebih baik. Oleh karenanya penulis selalu berharap apabila nantinya ada mahasiswa yang ingin meneliti dan ingin mengungkap mengenai baca-tulis, hendaknya melanjutkan dan melengkapi kekurangan yang ada dan mengkaji dari aspek lainnya yang masih belum disentuh.

\section{REFERENSI}

Al-kitab. (2001). Perjanjian lama dan baru dalam terjemahan baru (Jakarta: Yang diselenggerakan oleh lembaga Alkitab Indonesia).

Amna, Maryati. (2004). " Pembelajaran Menulis Integratif dan Komunikatif", Gerbang; Majalah Pendidikan, Edisi 2 Th IV.

Jurnal Eksos, Juni 2019, Th XV, No, 1
Agustian, Ari Ginanjar. (2005). New Edition, Rahasia Sukses Membangun Kecerdasan Emosi dan Spiritual (ESQ) Emotional Spiritual Quotient, the ESQ Way 165, 1 Ihsan 6 Rukun Iman dan 5 Rukun Islam (Jakarta: ARGA).

Departemen Pendidikan nasional. (2000). Kamus Bahasa Indonesia. Edisi ketiga Jakarta: Balai Pustaka.

Fekrynur. (1990). Membaca Himbauan Bagi Para Pejabat, yang dikutip dari bukunya Morris, A. and StewardDore, N: Learning to learn from text, Hodge, Bob: Communication and the teacher, (Meulborne: Longman Cheshire, 1985), (Addison-Wessley: NSW). E-Mail Address: <fekrynur@indosat.net.id>.

Mas'ud, Abdurrahman. (2002). Menggagas format pendidikan nondikotomik: Humanisme Religius Sebagai Paradigma Pendidikan Islam Yogyakarta: Gema Media.

Winarto, Leonardo. 4 Agustus (2006). Belajar memahami kesalah-pahaman hubungan Islam-Kristen, pada dialog Ma'had Aly Sukorejo-Situbondo.

Undang-Undang Republik Indonesia No. 20 tahun 2003. 2003. Tentang system Pendidikan Nasional (SISDIKNAS) (Bandung: Citra Umbara).

Tim Prima, Kamus lengkap bahasa Indonesia (Jakarta: Gitamedia Press)

Agung Kurniawan Budilaksono, Daniel. 1 2006-2007. Penerapan Pendidikan Kristen Perjanjian lama dalam era Modern ( Yayasan Lembaga Sabda (YLSA):, Disclaimer), http:/ /pepak.sabda.org/ pustaka/050919/ ?kata=perjanjian+lama.

Ahad, Abu. dan Unbiyat, Nur. (2001). Ilmu Pendidikan, (Djakarta: PT. Renika Cipta). 
Badjuri, Mahmudi. (2006). Prinsip-Prinsip Pendidikan Islam (Situbondo: Perpustakaan Fakultas Tarbiyah.

Bayrakly, Bayraktar. (2004). Prinsip Dan Metode Pendidikan Islam; sebuah paradigma baru pendidikan yang memanusiakan manusia. Jakarta: Inisiasi Press.

Djuwairiyah. (2006). "Ilmu Pendidikan", Diktat Fakultas Tarbiyah semester V Situbondo: Pustaka Fakultas Tarbiyah.

Gojali, Nanang. (2004). Manusia, Pendidikan Dan Sains Dalam Perspektif Tafsir Hermenuetik cet. 1. Jakarta: Renika Cipta.

Gangel, Kenneth. Membina Pemimpin Pendidikan Kristen, http:/ /pepak.sabda.org/ pustaka/050919/ ?kata=perjanjian+lama.

Homrighausen, E. G. dan Enklaar, I.H. (1993). Pendidikan Kristen dalam perjanjian baru, (BPK Gunung Mulia: Jakarta). 16 - 20. http:/ /pepak.sabda.org/ pustaka/050919/ ?kata=perjanjian+lama.

Hasbullah. (2001). Dasar-dasar ilmu pendidikan. Jakarta: PT. Raja Grafindo Persada.

Hasan, Cholidjah. (1995). Kajian perbandingan pendidikan. Surabaya: Al-Ikhlas.

Institusi pendidikan dalam Islam, Dari Wikipedia Bahasa Melayu, ensiklopedia bebas, $W W W$. Google.com. id. Pendidikan islam.

Kampus, Berhasil Mencapai Kejayaan; Panjang Sejarah Menulis \& Membaca Dalam Islam. Courtesy of www.perpustakaan-islam.com.

Moleong, Lexy J. (2004), Metode Penelitian Kualitatif. Bandung Remaja: Rosdakarya.

Mudji, Sutrisno dalam Imron Arifin. (1996). Ed. Penelitian kualitatif dalam ilmu- ilmu sosial dan keagamaan. Malang: Kalimasahada.

Mulyana, Dedy. tt. Metode Penelitian Kualitatif; Paradigma Baru Ilmu Komunikasi dan Social. Bandung: Rosdakarya.

Marzuki. (1999). Metodologi Riset. Yogyakarta: Hamindita.

Raharjo, Mudji (2002).Pengantar Penelitian bahasa. Malang: Cendekia Paramulya.

Sugiyono. (2005). Memahami penelitian kualitatif. Cet. I. Bandung: Alfabeta.

Syarifuddin, Ahmad. (2004). Mendidik anak membaca, menulis, dan mencintai Al-Qur'an. Jakarta: Gema Insani.

Tohirin. (2005). Psikologi Pembelajaran Pendidikan Agama Islam. Jakarta: PT. Raja Grafindo Persada.

Wilardjo, L. (1994). Studi Kasus: Sebuah Panduan Praktis. Jakarta: Satya Wacana University Press dan PT. Gramedia Widiasarana Indonesia.

Syamsul Hadi HM. (2002). Strategi Pengembangan Mutu Sumberdaya Guru di Lembaga Pendidikan Islam. Tesis. Tidak dipublikasikan. Malang: UNISMA.

Syaifullah. (2005). Muhammad Quthb \& Sistem Pendidikan non dikotomik. Cet. 1. Jakarta: Suluh Press.

Standar Kompetensi dan Kompetensi Dasar; Satuan Pendidikan: Sekolah Menengah Atas (SMA)/Sekolah Menengah Kejuruan (SMK). Mata Pelajaran: Pendidikan Agiama Kristen. www. Google.co.id. www.satuhala.blogspot.com.

Teguh Sutandio, Denny. Standar Penghakiman Allah-3 : Hukum Allah Vs Hukum Manusia-1 Nats : Roma 2:17-20. www.satuhala.blogspot.com. 
Subroto, B. Suryo. (2002). Proses Belajar Mengajar di sekolah. Jakarta: PT. Renika Cipta.

Rohani HM, Ahmad. (2004). Pengelolaan Pengajaran. Jakarta: PT. Renika Cipta.

The New Bible Dictionary. (2001). Ensiklopedi Al-Kitab masa kini. Jakarta: Yayasan Komunikasi Bina Kasih.

Hamalik, Oemar. (2003). Proses Belajar Mengajar. Jakarta: PT. Bumi Aksara.

Slameto. (2003). Belajar dan factor-faktor yang mempengaruhinya. Jakarta: PT. Renika Cipta.

Puji, Diambil dari Kitabul 'Ilmi, Syaikh Muhammad bin Shalih Al-Utsaimin, Belajar dalam islam: Tahapantahapan Dalam Belajar Ilmu Syar'I (Tanggal posting: 22-05-07), Courtesy of www.perpustakaan-islam.com.

Pekerti, Anugerah. (1988). Wawancara, Berita KPS Jakarta, eGroup home: http://www.eGroups.com/list/milisspiritual.

Pengenalan Sekolah Minggu; Training Guru Sekolah Minggu Kelas Pemula (GSM) (Disclaimer: Yayasan Lembaga SABDA (YLSA), (C) 2006-2007 ), Email: webmaster@sabda.org.

Teguh Sutandio, Denny. Standar Penghakiman Allah-3:Hukum Allah Vs Hukum Manusia- http://72. 14.207.104/search?q=cache:s6mQ9 VWqCQJ: nomind.3.forumer.com/a/

Hasibuan, JJ. Moedjiono. (2006). Proses Belajar Mengajar. Bandung: PT. Remaja Rosdakarya.

Soetjipto, kosasi, Raflis. (2004). Profesi Keguruan. Jakarta: PT. Renika Cipta.

Heri Jauhari Muchtar. (2005). Fikih Pendidikan. Bandung: PT. Remaja Rosdakarya.

Homrighausen, E. G. dan I.H. Enklaar, Pendidikan Kristen dalam perjanjian baru, (BPK Gunung Mulia: Jakarta, (1993), 16 - 20. http:/ /pepak.sabda.org/ pustaka/050919/ ?kata=perjanjian+lama.

The New Bible Dictionary. (2001). Ensiklopedi Al-Kitab masa kini (Jakarta: Yayasan Komunikasi Bina Kasih/omf ).

The New Bible Dictionary. (2001), Ensiklopedi Al-Kitab masa kini (Yayasan Komunikasi Bina Kasih/omf: Jakarta, Jilid 2 MZ), 248 yang dikutip dari Kepustakaan W barclay, Educational ideals in the Ascient world, 1959, ps 1,6; F.H Swift, Educational In Ancies Israel, 1919; E. B castle, Ancient Education and Today 1961, ps 5; TDNT 5, hal 596-625; IDB; EJ

Ash-shiddieqy, Hasbi TM.. (1973). Tafsir Al-Qur'an (x) djuz 28-30. Jakarta: Bulan Bintang. (2002). Tafsir Penjelas AlQur'anul Karim, juz 16-30. Semarang: PT. Pustaka Rizqi Putra.

Yunus, Mahmud. (1971). Tafsir Qur'an Karim. Djakarta: CV. Al-Hidayah.

Musthafa, Ahmad Al-Maghari. (1985). Terjemah tafsir al-maghari. Semarang: CV. Thaha Putra.

Ma'rifat, M. Hadi. (2007). Sejarah AlQur'an. Jakarta: El-Huda.

As-Sirjani, Raghib. (2007). penulis buku super best seller "Misteri Sholat subuh", Spiritual Reading; hidup lebih bermakna dengan membaca Solo: Aqwam.

Griffith, Mary. 1998). The Unschooling handbook: How to Use Whole World As Your Child's Classroom. United States: Prima Publishing, yang diterjemahkan oleh Mutia Dharma; Belajar tanpa sekolah: bagaimana memanfaatkan seluruh Dunia sebagai ruang kelas anak anda. Bandung: Nuansa. 2006. 
Kampus, Berhasil Mencapai Kejayaan; Panjang Sejarah Menulis \& Membaca Dalam Islam. Courtesy of www.perpustakaan-islam.com

Leonhardt, Mary. (2000). "Cinta membaca berarti cinta belajar; 99 cara menjadikan anak anda keranjingan membaca". Bulletin pusat pembukuan; Dengan buku jelajahi dunia, vol-4, no 1.

Mulardi, Eko. (2002). Menggiring Minat baca melalui majalah dinding". Bulletin pusat pembukuan; Dengan buku jelajahi dunia, vol-7, no 1.

Nggermanto, Agus. (2000). Quantum Questient (Kecerdasan Quantum); cara cepat melejitkan IQ, EQ, dan SQ secara harmonis. Bandung: Yayasan nuansa Cendekia.

Packer, J. I. Merril C. Tenney, William White. (2001). Ensiklopedi Fakta AlKitab (Bible Almanac), Buku rujukan Komperhensif yang direncanakan untuk mencari fakta tentang semua orang, tempat, dan adat istiadat di Alkitab Malang: Yayasan penerbit Gandum Mas.

Putu R. Ujianti, Menerapkan Strategi yang Tepat; Ajar Baca Tulis pada Anak Usia Dini, http://www.balipost.co.id/BaliPostcet $\mathrm{ak} / 2006 / 7 / 30 / \mathrm{kel} 1 . \mathrm{html}$.

Rahadi, Suko. (2004). "Membudaya bacakan masyarakat", Gerbang; Majalah Pendidikan. Edisi 3 th, IV.

Sihotang, Rudyanto. Reading Makes A Difference (Tue, 02/10/2007- 13:02 administrator, http//guide.gospelcom. net.

Sutioso. Andy. 25 Februari 2006. Pembelajaran baca tulis di semi palar; untuk Pertemuan Orang Tua Semi Palar,. http://www. semipalar.net/artikel/artikel25.html.

Sudibyo Bambang, 18 Maret 2006. Anak Usia Prasekolah Sebaiknya
Diarahkan pada Pembentukan Sikap, (Palangkaraya, : Kompas) http://kompas.com/kompascetak/0501/28/Jendela/1521570.htm.

Syarifuddin, Ahmad. (2004). Mendidik anak membaca, menulis, dan mencintai AlQur'an. Jakarta: Gema Insani.

The New Bible Dictionary. (2001). Ensiklopedi Al-Kitab masa kini. Jakarta: Yayasan Komunikasi Bina Kasih/omf.

Tresnawati, Heni. (2005). " Mengajak siswa untuk aktif Menulis", Gerbang. Majalah Pendidikan. Edisi 2 th. IV,12. 